\title{
Effect of fatty acid profile in vegetable oils and antioxidant supplementation on dairy cattle performance and milk fat depression
}

\author{
M. He and L. E. Armentano ${ }^{1}$ \\ Department of Dairy Science, University of Wisconsin, Madison 53706
}

\section{ABSTRACT}

This study was conducted to evaluate the effect of dietary supplementation of unprotected vegetable oils differing in fatty acid profiles with or without a commercial antioxidant (Agrado Plus, Novus International, St. Charles, MO) on dairy cattle performance, milk fatty acid profiles, and milk fat depression. Twentyfour multiparous Holstein cows were blocked by production (high and low) and assigned to Agrado Plus or no Agrado Plus diets as the main plot in this experiment. The 6 cows in each of the fixed effect groups (high with and without Agrado, low with and without Agrado) were then assigned to a $6 \times 6$ Latin square as a split plot with 21-d periods. The 6 dietary treatments in the split-plot Latin square were no added oil (control), or 5\% DM as oil from palm (PO), high-oleic safflower (OSAF), high-linoleic safflower (LSAF), linseed (LNSD), or corn (CO). Added oil replaced corn starch in the total mixed ration. Diets were formulated to have similar crude protein and neutral detergent fiber, and consisted of $41.2 \%$ alfalfa silage, $18.3 \%$ corn silage, and $40.5 \%$ concentrate mix (dry matter basis). Feeding Agrado Plus did not affect milk, milk fat, or milk protein production or milk fatty acid composition in this study. No significant differences were found between oil feeding versus control for dry matter intake, milk yield, and milk protein yield, but oils other than PO significantly decreased milk fat concentration and proportion and yield of milk short- and medium-chain fatty acids $\left(\mathrm{C}_{<16}\right)$. Feeding PO effectively maintained milk fat yield $(1.18 \mathrm{~kg} / \mathrm{d})$ and concentration (3.44\%), whereas the oils rich in linoleic acid (CO and LSAF) significantly decreased milk fat yield (0.98 and 0.86 vs. $1.14 \mathrm{~kg} / \mathrm{d}$ ) and concentration (3.05 and 2.83 vs. $3.41 \%$ ) compared with control. Similar lactation performance between OSAF and LNSD suggests that oleic and linolenic acids are roughly equal in potency of milk fat depression.

Key words: oleic, linoleic, linolenic, saturated fatty acid

Received August 24, 2010.

Accepted February 2, 2011.

${ }^{1}$ Corresponding author: learment@facstaff.wisc.edu

\section{INTRODUCTION}

Fat supplementation in dairy nutrition has been used for years to increase diet energy density and increase milk yield (Jenkins and McGuire, 2006). However, decreased milk fat yield (known as milk fat depression, MFD) and altered milk fatty acids (FA) composition can occur in diets containing unprotected unsaturated oils (Davis and Brown, 1970). Milk FA are mainly derived from 2 major sources, uptake of long-chain FA from peripheral circulation and de novo synthesis of short- and medium-chain FA in the mammary gland. Previous studies have shown that changes in milk fat yield following addition of unprotected vegetable oil to low-fat diets are consistent with inhibited de novo short- and medium-chain FA synthesis offset by increased delivery and uptake of long-chain FA from blood (Figure 1). Therefore, long-chain FA increase in proportion in milk fat, whereas short- and mediumchain FA represent a smaller proportion of milk fat compared with feeding diets without oil supplementation, regardless of whether oil feeding causes MFD or not. Bauman and Griinari (2001) proposed that under certain conditions, the pathways of rumen biohydrogenation are altered to produce unique FA intermediates that depress milk fat synthesis. These FA intermediates include trans-10,cis-12 conjugated linoleic acid (CLA; Baumgard et al., 2002), trans-9,cis-11 CLA (Perfield et al., 2007), cis-10,trans-12 CLA (Sæbø et al., 2005), and possibly trans-10 $\mathrm{C}_{18: 1}$ at greater amount (Shingfield et al., 2009), although other unidentified FA may also be inhibitors of de novo FA synthesis. The sum of their individual effects determines milk fat synthesis in the mammary gland.

It is difficult to compile data from different studies and compare the individual effect of each major FA on MFD because of the inevitable experiment-to-experiment variation in basal diet, stage of lactation, level of intake, and other factors. For those studies feeding vegetable oils at different levels, the effect of individual FA may also be confounded because levels of all FA in the diet are altered concurrently. The first objective of this study was to determine the effect of adding oils with widely different FA profiles on milk fat secretion. 
High-producing dairy cows may be susceptible to oxidative stress resulting from an imbalance between production of free radicals and their disposal (Sies, 1985). Dietary unprotected unsaturated FA can be significant contributors to the load of free radicals (Andrews et al., 2006). The resultant free radical is susceptible to attack by oxygen to form free radical peroxide, which then serves as a catalyst of further oxidation. Dairy cattle performance and health may be impaired by deficiencies of protective substances or excess exposure to substances that can stimulate production of reactive oxygen metabolites (Brzezinska-Slebodzinska et al., 1994). Including an antioxidant in the feed is one of the methods to inhibit the oxidation of dietary unsaturated fat sources and maintain dairy cattle performance. Agrado Plus (Novus International Inc., St. Charles, MO) is a commercial antioxidant product and its potential beneficial effects on dairy cattle health and performance have been investigated in several previous studies (Andrews et al., 2006; Vázquez-Añón and Jenkins, 2007; Vázquez-Añón et al., 2008). The second objective of this study was to examine the effect of Agrado Plus on dairy cattle performance and analyze whether or not this protection effect is dependent on the amount and profile of FA fed as free oils.

\section{MATERIALS AND METHODS}

\section{Animals and Treatments}

Twenty-four multiparous Holstein cows (106 to 211 DIM at the start of period 1) were divided by their average daily milk production for a week before experiment started (DairyComp 305, Valley Agricultural Software, Tulare, CA) into 2 blocks (high or low production) of 12 cows each. High-production cows averaged 149 DIM (106 to 211 DIM) and low-production cows averaged 158 DIM (107 to 196 DIM). Agrado Plus (0 or $0.025 \%$ of DM, - Agrado or + Agrado) was randomly assigned to 6 cows per block resulting in a main plot randomized block design with 1 df for production block, $1 \mathrm{df}$ for Agrado, $1 \mathrm{df}$ for Agrado by production interaction, and $20 \mathrm{df}$ for error. These 4 groups of 6 cows each (high + Agrado, high - Agrado, low + Agrado and low - Agrado) were each fed 6 diets (control and 5 oil diets) in a $6 \times 6$ Latin square design with 3 -wk periods as a split plot. The first $16 \mathrm{~d}$ of each period were for diet adaptation with the last $5 \mathrm{~d}$ for sample collection. Cows were milked twice daily at 0330 and $1530 \mathrm{~h}$, and milk weights were recorded at each milking. Bovine somatotropin (Posilac, Monsanto Co., St. Louis, MO) was injected every 2 wk. Animal use procedures were approved by the Animal Care and Use Committee for the College of Agricultural and Life Sciences at the University of Wisconsin-Madison.

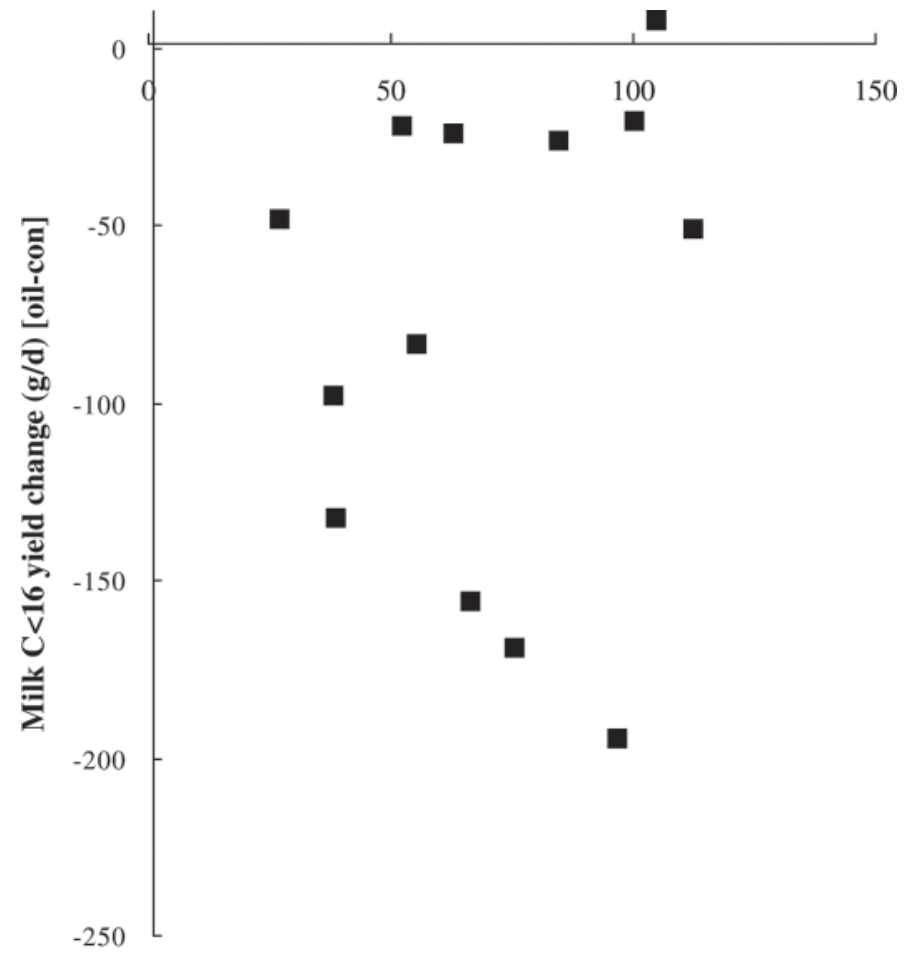

Milk total C18 yield change (g/d) [oil-con]

Figure 1. Effect of oil supplementation on milk fatty acids (FA) yield change compared with oil-free control diet. Data sources: Jenkins, 1998; DePeters et al., 2001; Leonardi et al., 2005; Bell et al., 2006; Bu et al., 2007; AlZahal et al., 2008; Huang et al., 2008; Abdelqader et al., 2009; Chilliard et al., 2009. Milk FA yields come directly from studies cited or are calculated as milk FA $\% \times$ milk fat yield $\times 93.3 \%$, assuming total milk FA account for $93.3 \%$ of milk total lipids (Glasser et al. 2007). [Oil-con] = milk FA yield difference between feeding oil supplementation diet and an oil-free control diet within each experiment.

Cows were kept in tie-stalls and were fed a TMR twice daily with free access to water. Corn silage, alfalfa silage, concentrate mix, and respective vegetable oils were mixed once daily before morning feeding and offered ad libitum to allow for $10 \%$ refusals on an as-fed basis. As-fed diet composition was adjusted weekly to account for forage DM change. Diets were formulated to meet the requirements of the National Research Council (NRC, 2001), based on cows at 80 DIM, weighing $680 \mathrm{~kg}$, producing $40 \mathrm{~kg}$ of milk daily with $3.5 \%$ milk fat and $3.0 \%$ milk true protein, and with a target DMI of $25.0 \mathrm{~kg} / \mathrm{d}$. The control diet consisted of $18.3 \%$ corn silage, $41.2 \%$ alfalfa silage, and $40.5 \%$ concentrate mix on a DM basis (Table 1).

Dietary treatments (12 in total) were no added oil (control) with or without Agrado Plus (0.025\% DM) or $5 \% \mathrm{DM}$ as unprotected oil. The oil treatments were made by replacing $5 \%$ DM from corn starch with palm oil (PO; Columbus Foods, DesPlaines, IL), high-oleic safflower oil (OSAF; Columbus Foods), high-linoleic safflower oil (LSAF; Jedwards Int. Inc., Quincy, MA), 
Table 1. Ingredient and chemical composition of experimental diets

\begin{tabular}{|c|c|c|}
\hline Item & Control & $\begin{array}{c}\text { Oil } \\
\text { treatments }\end{array}$ \\
\hline \multicolumn{3}{|l|}{ Ingredients ( $\mathrm{g} / 100 \mathrm{~g}$ of $\mathrm{DM})$} \\
\hline Alfalfa silage & 41.2 & 41.2 \\
\hline Corn silage $^{2}$ & 18.3 & 18.3 \\
\hline Corn starch & 10.0 & 5.0 \\
\hline Vegetable oil ${ }^{3}$ & - & 5.0 \\
\hline Dry ground shelled corn & 6.8 & 6.8 \\
\hline Soybean meal, $48 \% \mathrm{CP}$ & 6.8 & 6.8 \\
\hline Corn gluten meal & 1.8 & 1.8 \\
\hline Beet pulp, dried & 4.8 & 4.8 \\
\hline Molasses, sugarcane & 3.7 & 3.7 \\
\hline Corn gluten feed, dried & 2.8 & 2.8 \\
\hline Soybean hulls & 2.8 & 2.8 \\
\hline Dicalcium phosphate & 0.3 & 0.3 \\
\hline Salt & 0.2 & 0.2 \\
\hline Magnesium oxide & 0.2 & 0.2 \\
\hline Trace mineral salt ${ }^{4}$ & 0.2 & 0.2 \\
\hline Vitamin A, D, and E premix ${ }^{5}$ & 0.2 & 0.2 \\
\hline Calcium carbonate & 0.1 & 0.1 \\
\hline \multicolumn{3}{|l|}{ Chemical composition } \\
\hline $\mathrm{NE}_{\mathrm{L}}^{6}(\mathrm{Mcal} / \mathrm{kg})$ & 1.61 & 1.73 \\
\hline $\mathrm{CP}(\%)$ & 17.0 & 16.6 \\
\hline $\operatorname{NDF}(\%)$ & 29.9 & 29.0 \\
\hline $\operatorname{ADF}(\%)$ & 22.2 & 22.1 \\
\hline Starch $(\%)$ & 17.2 & 14.6 \\
\hline Ether extract ${ }^{7}(\%)$ & 1.9 & 6.8 \\
\hline Ash (\%) & 8.2 & 8.1 \\
\hline $\mathrm{Ca}(\%)$ & 0.95 & 0.96 \\
\hline $\mathrm{P}(\%)$ & 0.34 & 0.34 \\
\hline
\end{tabular}

${ }^{1}$ Alfalfa silage: $37.6 \% \mathrm{NDF}, 20.7 \% \mathrm{CP}, 10.5 \%$ ash, and $2.5 \%$ fat (DM basis).

${ }^{2}$ Corn silage: $39.9 \%$ NDF, $9.2 \%$ CP, $5.1 \%$ ash, and $2.8 \%$ fat (DM basis).

${ }^{3}$ Palm, high-oleic safflower, high-linoleic safflower, linseed, or corn oil. ${ }^{4}$ Contained $0.55 \% \mathrm{Mg}, 0.55 \% \mathrm{Zn}, 0.35 \% \mathrm{Fe}, 0.14 \% \mathrm{Cu}, 0.008 \% \mathrm{I}$, $0.006 \%$ Se, and $0.002 \%$ Co.

${ }^{5}$ Contained 1,500 IU/g of DM of vitamin A, $500 \mathrm{IU} / \mathrm{g}$ of $\mathrm{DM}$ of vitamin $\mathrm{D}$, and $5 \mathrm{IU} / \mathrm{g}$ of $\mathrm{DM}$ of vitamin $\mathrm{E}$.

${ }^{6}$ Predicted by NRC (2001).

${ }^{7}$ Ether extract content of 5 vegetable oils was not analyzed; assumed vegetable oils have $99.9 \%$ ether extract (NRC, 2001).

linseed oil (LNSD; Cargill Inc., Minneapolis, MN), or corn oil (CO; Columbus Foods). To choose the oils used in this study, $\mathrm{C}_{16: 0}, \mathrm{C}_{18: 0}, \mathrm{C}_{18: 1}, \mathrm{C}_{18: 2}, \mathrm{C}_{18: 3}$, and the sum of all other FA (\% of total FA) for several vegetable oils were analyzed by principal component analysis (PRINCOMP procedure, version 9.1, SAS Institute Inc., Cary, NC; Figure 2). Principal component analysis aims to explain the maximum amount of variation in the numerous, often correlated, original variables with fewer, orthogonal principal components. In this study, principal components 1 and 2 described 33.2 and $27.0 \%$ of the total variation in oil FA, respectively. Palm oil, high-oleic safflower oil, high-linoleic safflower oil, and linseed oil were selected thereafter to represent oils that varied the most in FA composition and represented oils rich in $\mathrm{C}_{16: 0}, \mathrm{C}_{18: 1}, \mathrm{C}_{18: 2}$, and $\mathrm{C}_{18: 3}$, respectively. Corn oil was included in this experiment because it is present

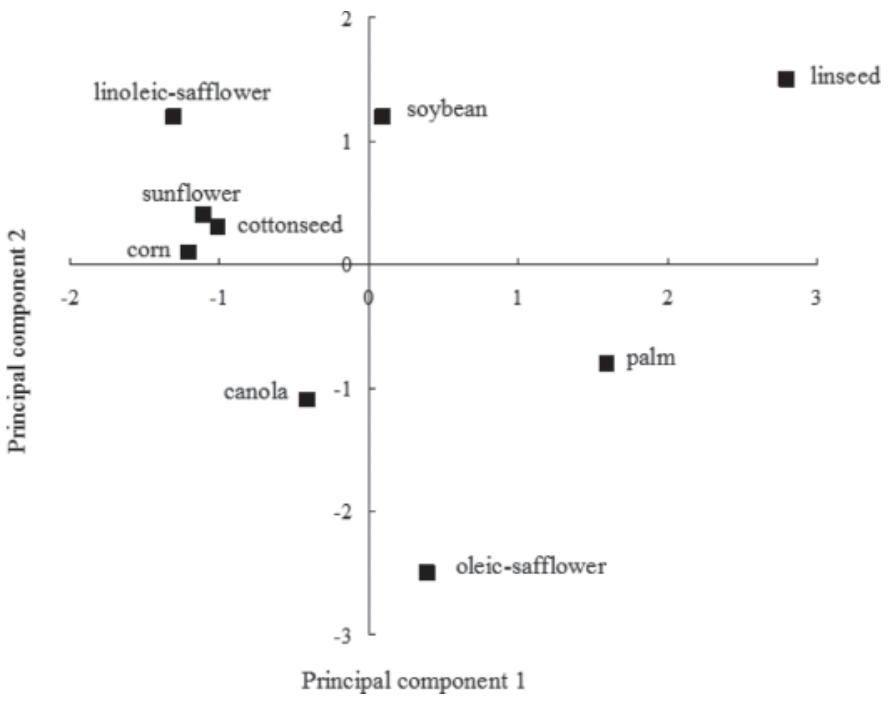

Figure 2. Loading plot, describing the relationship among oils derived from principal component analysis based on vegetable oil fatty acid (FA) composition (\% of total FA) of $\mathrm{C}_{16: 0}, \mathrm{C}_{18: 0}, \mathrm{C}_{18: 1}, \mathrm{C}_{18: 2}, \mathrm{C}_{18: 3}$, and sum of all other FA.

in many common feedstuffs including corn grain, corn silage, and corn processing byproducts.

One concentrate mix was formulated for the control diet and a second mix for the oil diets. Oil, forages, concentrate, and concentrate containing $1.25 \%$ Agrado Plus were mixed daily in a Rissler TMR cart (model 450, Rissler, Mohnton, PA). The sequence of treatments in the Latin square was selected to balance for one period carryover effect. Diets were formulated to have similar CP and NDF. Oils were kept under nitrogen gas to minimize oxidation.

\section{Sampling and Analysis}

Corn silage and alfalfa silage were sampled weekly and concentrate mixes were sampled every 2 wk. Samples were dried at $60^{\circ} \mathrm{C}$ for $48 \mathrm{~h}$ to determine DM. Amount of feeds offered and refusals for individual cows were recorded daily, and values for the last $5 \mathrm{~d}$ of each period were used to calculate DMI, assuming the DM of refusal was equal to the DM of feed offered. Feed samples were then ground to pass a 1-mm screen (Wiley mill, Arthur H. Thomas, Philadelphia, PA), composited for the whole trial, and analyzed for DM, ash, NDF, ADF, $\mathrm{CP}$, ether extract, starch, mineral content, and FA profile $(\mathrm{g} / \mathrm{kg}$ of $\mathrm{DM})$.

The analytical DM of feed samples for composition analysis was determined according to National Forage Testing Association method 2.1.4 by drying in a $105^{\circ} \mathrm{C}$ forced-air oven for $3 \mathrm{~h}$ (Understander et al., 1993). Ash content was measured following AOAC method 
942.05 (AOAC, 1997) by oven combustion at $600^{\circ} \mathrm{C}$ for $2 \mathrm{~h}$. Neutral detergent fiber was determined using $\alpha$-amylase (Sigma Chemical Co., St. Louis, MO) and sodium sulfite according to Van Soest et al. (1991) and Goering and Van Soest (1970). Acid detergent fiber was analyzed on separate samples using AOAC method 973.18 (AOAC, 1997). Crude protein was determined by combustion method (AOAC, 1997; method 990.03) using a Leco 428 combustion analyzer (Leco Corp., St. Joseph, MI). Ether extract was analyzed using AOAC method 920.39 (AOAC, 1997). Total starch was determined according to the enzymatic-colorimetric method of Bach Knudsen (1997). Feed FA content (g/ $\mathrm{kg}$ of DM) was determined following the procedure of Sukhija and Palmquist (1988). The percentage total FA was calculated by adding each $\mathrm{FA}$ from $\mathrm{C}_{12: 0}$ to $\mathrm{C}_{22: 0}$, with $\mathrm{C}_{19: 0}$ used as internal standard. Mineral content of feedstuffs was determined at Dairyland Laboratories Inc. (Arcadia, WI; AOAC, 1997; method 985.01). Diet chemical composition was calculated based on analysis of individual feedstuffs (Table 1).

Milk production was recorded daily, and milk samples were collected the last $5 \mathrm{~d}$ of each period. Concentrations of fat, true protein, and lactose in individual a.m. and p.m. samples were determined by infrared analysis using a Foss FT6000 (AgSource Laboratory, Menomonie, WI). A second set of a.m. and p.m. milk samples was collected on d 19 and 20 of each period, pooled by volume according to production at each milking for each day, and centrifuged at $17,800 \times g$ for $30 \mathrm{~min}$ at $8^{\circ} \mathrm{C}$. Milk fat was collected and stored at $-20^{\circ} \mathrm{C}$ until FA analysis. Lipid extraction and FA methylation were performed according to the method described by Chouinard et al. (1999). Resulting FA methyl esters were injected in a gas chromatograph (Perkin Elmer Autosystem, Norwalk, CT) equipped with a 100-m (0.25 mm i.d.) WCOT fused-silica capillary column wall coated with CP-Sil 88 (Chrompack \#CP7489, Varian Inc., Walnut Creek, CA). Helium was the carrier gas. Each sample was analyzed under 3 different conditions. First, total FA profile was determined by a temperature gradient run $\left(50\right.$ to $190^{\circ} \mathrm{C}$ at $\left.4^{\circ} \mathrm{C} / \mathrm{min}\right)$. Second, an isothermal run $\left(160^{\circ} \mathrm{C}\right)$ was used to separate cisand trans-octadecenoic FA. Third, another isothermal run $\left(180^{\circ} \mathrm{C}\right)$ was used to separate cis-9 octadecenoic FA peaks. Peaks were identified utilizing individual FA from Supelco Inc. (Bellefonte, PA), Sigma Chemical Co., and Matreya Inc. (Pleasant Gap, PA). Response factors for each FA methyl ester were obtained based on analysis of certified butterfat (CRM 164, Commission of the European Communities, Community Bureau of Reference, Brussels, Belgium) and were applied to adjust individual areas' mass proportion. Response factors for FA not in the certified butterfat standard were calculated as an average of the certified FA that eluted before and after them.

\section{Statistical Analysis}

Data were analyzed using the MIXED procedure of SAS (Version 9.1, SAS Institute Inc., Cary, NC). Variables were analyzed using the model

$$
\begin{aligned}
\mathrm{Y} & =\mu+\mathrm{A}+\mathrm{Pr}+(\mathrm{A} \times \mathrm{Pr})+\mathrm{C}+\mathrm{O}+(\mathrm{A} \times \mathrm{O}) \\
& +(\mathrm{Pr} \times \mathrm{O})+\mathrm{P}+(\mathrm{P} \times \mathrm{A})+(\mathrm{P} \times \mathrm{Pr})+\mathrm{e},
\end{aligned}
$$

where $\mathrm{Y}$ is the response variable; $\mu$ is the overall mean; $\mathrm{A}$ is the fixed effect of antioxidant; Pr is the fixed effect of production block; $\mathrm{C}$ is the random effect of cow within main-plot; $\mathrm{O}$ is the fixed effect of oil treatments; $\mathrm{P}$ is the fixed effect of period; and e is the random residual error. Preplanned contrast statements were included to test the effects of oil supplementation (control vs. average of 5 oils), FA chain length (PO vs. average of other 4 oils), and FA unsaturation (OSAF vs. LSAF, $\mathrm{C}_{18: 1}$ vs. $\mathrm{C}_{18: 2}$; LSAF vs. LNSD, $\mathrm{C}_{18: 2}$ vs. $\mathrm{C}_{18: 3}$; OSAF vs. LNSD, $\mathrm{C}_{18: 1}$ vs. $\left.\mathrm{C}_{18: 3}\right)$ within oil main effect. Reported values were least squares means with significance declared at $P<0.05$ and trend declared at $P<0.10$.

\section{RESULTS AND DISCUSSION}

\section{Intakes, Milk Production, and Milk Composition}

One cow was removed from this experiment during the last period because of foot injury. Her data for the first 5 periods were used in this study. Palm oil, OSAF, CO, LSAF, and LNSD were abundant in $\mathrm{C}_{16: 0}, \mathrm{C}_{18: 1}$, $\mathrm{C}_{18: 2}, \mathrm{C}_{18: 2}$, and $\mathrm{C}_{18: 3}$, respectively (Table 2 ). The ingredient and nutrient composition of experimental diets are presented in Table 1. The control treatment and the 5 oil treatments had similar nutrient composition except for starch and ether extract content.

The effect of supplemental fat on DMI is variable, usually resulting in no change or a decrease in DMI (Chilliard, 1993). The level of vegetable oil supplementation in this study was chosen to avoid detrimental effects on DMI, thus minimizing the interference of milk long-chain FA from body fat mobilization. In our study, feeding mid-lactation dairy cattle unprotected vegetable oils at $5 \%$ of DM had no negative influence on DMI and milk yield compared with the control (Table 3). This is in agreement with results from other studies in which DMI was not affected when $4 \%$ soybean or flaxseed oil (Bu et al., 2007), 5\% sunflower or linseed oil (Loor et al., 2005b), or $6 \%$ safflower oil or linseed oil (Bell et al., 2006) were fed to dairy cattle. Feeding oils with 
Table 2. Major fatty acid (FA) composition of vegetable oils fed

\begin{tabular}{lrcccc}
\hline & \multicolumn{5}{c}{ Vegetable oil } \\
\cline { 2 - 6 } FA (\% of & Palm & Oleic-safflower & Linseed & Corn & Linoleic-safflower \\
\hline total FA) & 38.8 & 4.9 & 5.3 & 11.3 & 6.8 \\
\hline $\mathrm{C}_{16: 0}$ & 4.2 & 2.1 & 4.8 & 1.8 & 2.7 \\
$\mathrm{C}_{18: 0}$ & 43.6 & 79.1 & 22.5 & 27.2 & 15.0 \\
$\mathrm{C}_{18: 1}$ & 11.0 & 12.7 & 15.7 & 57.8 & 74.7 \\
$\mathrm{C}_{18: 2}$ & 0.6 & 0.8 & 50.3 & 1.3 & 0.2 \\
$\mathrm{C}_{18: 3}$ & 1.8 & 0.4 & 1.4 & 0.6 & 0.6 \\
Other & & & & & \\
\hline
\end{tabular}

different unsaturation levels had no significant effect on DMI in our study (Table 3). In contrast to our results, Pantoja et al. (1994) reported that DMI was linearly decreased by increased fat unsaturation.

Milk yield was increased by feeding PO compared with feeding other 4 oils, whereas cows had similar milk yield when fed PO or the control diet (Table 3). Feeding $\mathrm{C}_{18: 2}$-rich LSAF significantly decreased milk yield compared with feeding $\mathrm{C}_{18: 1}$-rich OSAF or $\mathrm{C}_{18: 3}$-rich LNSD.

Depression in milk protein concentration has been observed in some studies when oil or fat is supplemented to dairy cows (Wu and Huber, 1994; Dhiman et al., 2000). Many other studies, including ours, have demonstrated that milk protein yield remains unchanged with vegetable oil supplementation (Zheng et al., 2005; Bell et al., 2006; Bu et al., 2007). Milk protein concentrations were significantly less $(P<0.05)$ when feeding the control, PO, OSAF, or LNSD treatments than when feeding LSAF, but milk protein yield was not significantly different across all treatments. Therefore, it appears that the decrease in milk protein concentration is caused by a dilution effect rather than by inhibition of protein synthesis (DePeters and Cant, 1992).

Feeding PO resulted in the greatest milk fat yield and fat concentration among all treatments including control, whereas feeding either of the $2 \mathrm{C}_{18: 2}$-rich oils (CO and LSAF) significantly decreased milk fat yield and concentration compared with control and compared with PO $(P<0.05)$. The effects of feeding palmitic acid $\left(\mathrm{C}_{16: 0}\right)$ on milk fat yield were examined by several previous studies. Feeding $10 \% \mathrm{C}_{16: 0}(>85 \%$ pure) increased the total yield of milk fat (Steele and Moore, 1968; Nobles et al., 1969). Similarly, Banks et al. (1976) found that supplementation of $517 \mathrm{~g} / \mathrm{d}$ of palm oil containing $62 \% \mathrm{C}_{16: 0}$ resulted in a $20 \%$ increased milk fat concentration compared with control treatment. Supplementation with $\mathrm{C}_{16: 0}$ or free palm oil rich in esterified $\mathrm{C}_{16: 0}$ is an effective method to increase dairy cattle energy intake without the negative effects on milk fat synthesis.

Dietary supplementation of unprotected unsaturated FA, however, has been proven to decrease milk fat yield
(Jenkins, 1998) and milk fat concentration (Jenkins, 1998; Dhiman et al., 2000; DePeters et al., 2001). Our result that feeding $5 \%$ dietary corn oil or LSAF caused significant MFD (Table 3) was supported by other research in which decreased milk fat yield and concentration were observed when cows were fed $\mathrm{C}_{18: 2}$-rich oils including $6 \%$ safflower oil (Bell et al., 2006), 3.6 or $4 \%$ soybean oil (Dhiman et al., 2000), and $3.4 \%$ soybean oil (AlZahal et al., 2008).

Feeding OSAF or LNSD in our trial resulted in very similar milk fat yields and concentrations. These diets also resulted in similar yields of summed $\mathrm{FA} \mathrm{C}_{<16}$, and $\mathrm{C}_{16: 0}$ and were both lower than the control diet for these FA (Table 4). We speculate that dietary $\mathrm{C}_{18: 1}$ and $\mathrm{C}_{18: 3}$ have similar potency for MFD, because the difference in dietary $\mathrm{C}_{18: 1}$ and $\mathrm{C}_{18: 3}$ between OSAF and LNSD is large, whereas differences in other FA are minor, although these diets also vary slightly in C18:0 and C18:2 content. In addition, much of the MFD observed in this study with OSAF and LNSD could be due to the $\mathrm{C}_{18: 2}$ in the diets, because diets OSAF and LNSD had approximately twice the $\mathrm{C}_{18: 2}$ concentration as the control (Table 5). Although the PO diet also contained more $\mathrm{C}_{18: 2}$ than the control, the negative effect of $\mathrm{C}_{18: 2}$ on milk $\mathrm{C}_{<16}$ and $\mathrm{C}_{16}$ yield from de novo synthesis was probably counteracted by the provision of preformed $\mathrm{C}_{16: 0}$ (Table 4).

Dietary supplementation with $0.025 \%$ DM Agrado Plus did not appear to have any independent effect on DMI, milk yield, milk fat, protein, and lactose yield or concentration in this study (Table 3). Agrado by oil interactions were not detected for any of these parameters $(P>0.05)$. This response is in contrast to results in other research that showed increased DMI, milk fat yield, 3.5\% FCM yield, and tendency of milk yield increase for Agrado Plus supplemented versus nonsupplemented dairy cows (Vazquez-Anon et al., 2008).

\section{Milk FA Composition and Yield}

The addition of PO, OSAF, LNSD, CO, and LSAF increased the level of $\mathrm{C}_{16: 0}, \mathrm{C}_{18: 1}, \mathrm{C}_{18: 3 \mathrm{n}-3}, \mathrm{C}_{18: 2 \mathrm{n}-6}$, and 


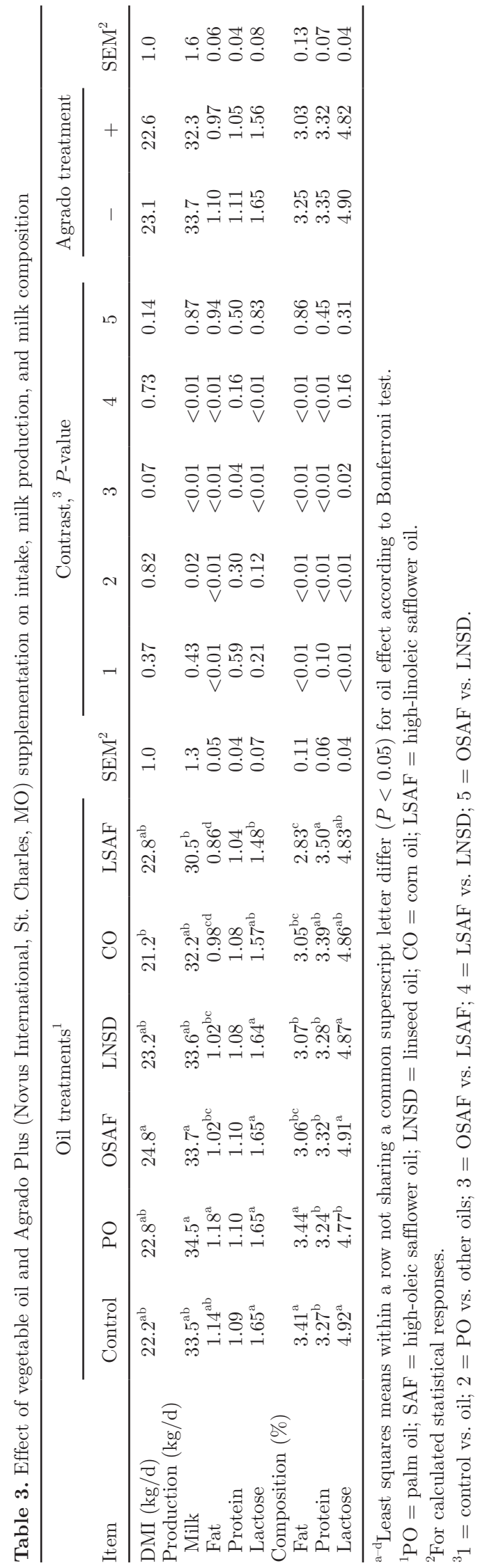

$\mathrm{C}_{18: 2 \text { n- } 6}$ in milk fat, respectively, compared with the control, as we expected (Table 6).

In the current study, when $\mathrm{PO}$ was fed, milk $\mathrm{C}_{16: 0}$, $\mathrm{C}_{16: 1}$ cis-9, and total $\mathrm{C}_{18: 1}$ yields were significantly increased compared with control, yields of $\mathrm{C}_{18: 0}$ and $\mathrm{C}_{18: 2}$ were unaffected, and $\mathrm{C}_{<16}$ (that are mostly synthesized de novo in the mammary gland) were significantly decreased (Table 4). We cannot determine from this study if $\mathrm{C}_{16: 0}$ had a depressing effect on shorter chain FA secretion, due to the presence of considerable $\mathrm{C}_{18: 1}$ and $\mathrm{C}_{18: 2}$ in palm oil. In the current study, the overall effect of palm oil feeding to maintain milk fat yield suggests that the inhibition of $\mathrm{C}_{<16}$ by palm oil can be successfully compensated by mammary gland uptake of $16 \mathrm{C}$ and $18 \mathrm{C} \mathrm{FA}$ in palm oil. In another study, duodenal infusion of $98.6 \%$ pure $\mathrm{C}_{16: 0}$ only increased milk $\mathrm{C}_{16: 0}$ yield but had no effect on major short- and mediumchain FA yield (Enjalbert et al., 2000). The relatively pure $\mathrm{C}_{16: 0}$ and bypass of ruminal effects (Enjalbert et al., 2000) can both explain the lack of a detrimental effect on milk short- and medium-chain FA secretion. However, decreased concentration and yield of shortand medium-chain FA were reported when cows were fed $10 \%$ DM $96 \%$ pure $\mathrm{C}_{16: 0}$ (Steele and Moore, 1968) or $85 \%$ pure $\mathrm{C}_{16: 0}$ (Nobles et al., 1969). These results indicated that even dietary $\mathrm{C}_{16: 0}$ might inhibit shortand medium-chain FA de novo synthesis because either $\mathrm{C}_{18: 1}$ or $\mathrm{C}_{18: 2}$ represented less than $2 \%$ of total $\mathrm{FA}$ fed.

Increasing cis-9,trans-11 CLA level in milk may be desirable because of its beneficial effect on human health (McGuire and McGuire, 2000). Previous work showed that increasing the level of $\mathrm{C}_{18: 2}$ (Kelly et al., 1998) or $\mathrm{C}_{18: 3}$ (Chouinard et al., 1998) in the cow's diet can increase the proportion of cis-9, trans-11 CLA in total milk FA. Feeding dairy cattle with unsaturated vegetable oils, resulting in decreased milk fat synthesis, as we discussed previously, is also shown to be associated with enhanced levels of trans- $11 \mathrm{C}_{18: 1}$ and cis-9,trans-11 CLA in milk fat (Dhiman et al., 2000). Although milk fat yields when feeding CO and LSAF were significantly less than when feeding the control diet, the yields of trans-11 $\mathrm{C}_{18: 1}$ and cis-9,trans-11 CLA for CO and LSAF were still more than 2 times greater than those for control $(P<0.05)$. Trans-11 $\mathrm{C}_{18: 1}$ has been shown to be the major trans- $\mathrm{C}_{18: 1} \mathrm{FA}$ isomer produced from rumen biohydrogenation under typical dietary conditions (Griinari and Bauman, 1999). Other studies estimated that endogenous synthesis of cis-9,trans-11 CLA from trans- $11 \mathrm{C}_{18: 1}$ accounts for approximately 78 to $85 \%$ of the CLA in milk fat (Corl et al., 2001; Lock and Garnsworthy, 2002). Lock and Garnsworthy (2002) found that amounts of trans- $11 \mathrm{C}_{18: 1}$ and cis-9,trans-11 CLA flowing through the duodenum were greater in cows fed diets supplemented with oils rich in $\mathrm{C}_{18: 2}$ compared 
Table 4. Effect of vegetable oil and Agrado Plus (Novus International, St. Charles, MO) supplementation on milk fatty acid yield ${ }^{1}$

\begin{tabular}{|c|c|c|c|c|c|c|c|c|c|c|c|c|c|c|c|}
\hline \multirow{2}{*}{$\begin{array}{l}\text { Fatty acid } \\
(\mathrm{g} / \mathrm{d})\end{array}$} & \multicolumn{6}{|c|}{ Oil treatment $^{2}$} & \multirow[b]{2}{*}{ SEM } & \multicolumn{5}{|c|}{ Contrast,${ }^{3} P$-value } & \multicolumn{2}{|c|}{ Agrado treatment } & \multirow[b]{2}{*}{ SEM } \\
\hline & Control & $\mathrm{PO}$ & OSAF & LNSD & $\mathrm{CO}$ & LSAF & & 1 & 2 & 3 & 4 & 5 & - & + & \\
\hline 4:0 & $42.42^{\mathrm{ab}}$ & $43.94^{\mathrm{a}}$ & $35.63^{\mathrm{abc}}$ & $35.97^{\mathrm{abc}}$ & $33.75^{\mathrm{bc}}$ & $29.01^{\mathrm{c}}$ & 3.29 & 0.14 & $<0.01$ & 0.04 & 0.03 & 0.91 & 40.53 & 33.04 & 3.57 \\
\hline 6:0 & $24.67^{\mathrm{a}}$ & $20.39^{\mathrm{b}}$ & $15.88^{\mathrm{c}}$ & $15.70^{\mathrm{c}}$ & $14.24^{\mathrm{c}}$ & $12.85^{\mathrm{c}}$ & 1.50 & $<0.01$ & $<0.01$ & 0.03 & 0.04 & 0.90 & 18.93 & 15.65 & 1.67 \\
\hline 8:0 & $13.61^{\mathrm{a}}$ & $9.43^{\mathrm{b}}$ & $7.57^{\mathrm{bc}}$ & $7.41^{\mathrm{bc}}$ & $6.61^{\mathrm{c}}$ & $5.78^{\mathrm{c}}$ & 0.73 & $<0.01$ & 0.14 & 0.01 & $\begin{array}{l}0.04 \\
0.02\end{array}$ & 0.82 & $\begin{array}{r}10.90 \\
9.25\end{array}$ & $\begin{array}{r}10.00 \\
7.55\end{array}$ & 0.80 \\
\hline 10:0 & $28.66^{\mathrm{a}}$ & $17.76^{\mathrm{b}}$ & $14.43^{\mathrm{bc}}$ & $14.13^{\mathrm{bc}}$ & $12.74^{\mathrm{c}}$ & $11.46^{\mathrm{c}}$ & 1.43 & $<0.01$ & 0.62 & 0.04 & 0.07 & 0.84 & 18.14 & 14.93 & 1.49 \\
\hline 12:0 & $35.86^{\mathrm{a}}$ & $22.05^{\mathrm{b}}$ & $18.94^{\mathrm{bc}}$ & $18.09^{\mathrm{bc}}$ & $16.67^{\mathrm{c}}$ & $15.34^{\mathrm{c}}$ & 1.58 & $<0.01$ & $\begin{array}{l}0.99 \\
0.99\end{array}$ & 0.03 & $\begin{array}{l}0.09 \\
0.09\end{array}$ & 0.60 & $\begin{array}{l}10.14 \\
22.95\end{array}$ & 19.37 & 1.64 \\
\hline 14:0 & $112.22^{\mathrm{a}}$ & $85.50^{\mathrm{b}}$ & $76.44^{\mathrm{bc}}$ & $71.80^{\mathrm{bcd}}$ & $66.72^{\mathrm{cd}}$ & $61.65^{\mathrm{d}}$ & $\begin{array}{l}1.00 \\
4.83\end{array}$ & $<0.01$ & $\begin{array}{l}0.99 \\
0.19\end{array}$ & $<0.01$ & 0.03 & 0.32 & $\begin{array}{l}22.90 \\
84.83\end{array}$ & $\begin{array}{l}19.01 \\
73.28\end{array}$ & $\begin{array}{l}1.04 \\
5.21\end{array}$ \\
\hline $14: 1$ & $12.34^{\mathrm{a}}$ & $10.02^{\mathrm{ab}}$ & $9.87^{\mathrm{b}}$ & $8.23^{\mathrm{b}}$ & $7.94^{\mathrm{b}}$ & $7.85^{\mathrm{b}}$ & 0.73 & $<0.01$ & 0.48 & 0.01 & 0.63 & 0.04 & $10.43^{\mathrm{A}}$ & $8.32^{\mathrm{B}}$ & 0.71 \\
\hline $15: 0$ & $11.01^{\mathrm{a}}$ & $8.05^{\mathrm{b}}$ & $7.49^{\mathrm{bc}}$ & $7.06^{\mathrm{bcd}}$ & $6.61^{\mathrm{cd}}$ & $6.04^{\mathrm{d}}$ & 0.41 & $<0.01$ & 0.65 & $<0.01$ & $\begin{array}{l}0.00 \\
0.02\end{array}$ & $\begin{array}{l}0.04 \\
0.30\end{array}$ & $\begin{array}{r}10.40 \\
8.25\end{array}$ & $\begin{array}{l}0.02 \\
7.17\end{array}$ & $\begin{array}{l}0.11 \\
0.42\end{array}$ \\
\hline$<16: 0$ & $294.44^{\mathrm{a}}$ & $227.21^{\mathrm{b}}$ & $194.42^{\text {bc }}$ & $186.93^{\mathrm{bc}}$ & $172.61^{\mathrm{c}}$ & $156.39^{\mathrm{c}}$ & $\begin{array}{r}0.41 \\
14.00\end{array}$ & $<0.01$ & $\begin{array}{l}0.00 \\
0.08\end{array}$ & $<0.01$ & $\begin{array}{l}0.02 \\
0.02\end{array}$ & 0.58 & 223.23 & 187.44 & $\begin{array}{r}0.42 \\
15.20\end{array}$ \\
\hline $16: 0$ & $288.78^{\mathrm{b}}$ & $346.05^{\mathrm{a}}$ & $201.86^{\mathrm{c}}$ & $183.57^{\mathrm{c}}$ & $192.51^{\mathrm{c}}$ & $167.48^{\mathrm{c}}$ & 14.22 & $<0.01$ & $<0.01$ & 0.03 & 0.30 & 0.24 & 248.36 & 211.72 & 13.90 \\
\hline $16: 1$ cis-9 & $21.21^{\mathrm{b}}$ & $29.01^{\mathrm{a}}$ & $17.95^{\mathrm{bc}}$ & $15.89^{\mathrm{c}}$ & $16.65^{\mathrm{c}}$ & $14.93^{\mathrm{c}}$ & $\begin{array}{r}14.22 \\
1.24\end{array}$ & $<0.01$ & $<0.01$ & $\begin{array}{l}0.00 \\
0.02\end{array}$ & $\begin{array}{l}0.50 \\
0.44\end{array}$ & $\begin{array}{l}0.24 \\
0.10\end{array}$ & $\begin{array}{r}240.00 \\
21.40^{\mathrm{A}}\end{array}$ & $17.15^{\mathrm{B}}$ & $\begin{array}{r}10.90 \\
1.30\end{array}$ \\
\hline $17: 0$ & $3.95^{\mathrm{a}}$ & $2.92^{\mathrm{b}}$ & $2.79^{\mathrm{b}}$ & $2.76^{\mathrm{b}}$ & $2.59^{\mathrm{b}}$ & $2.39^{\mathrm{b}}$ & 0.15 & $<0.01$ & 0.73 & 0.02 & 0.04 & 0.85 & 3.08 & 2.72 & 0.14 \\
\hline 18:0 & $80.17^{\mathrm{ab}}$ & $83.40^{\mathrm{ab}}$ & $97.60^{\mathrm{a}}$ & $88.88^{\mathrm{ab}}$ & $85.24^{\mathrm{ab}}$ & $73.77^{\mathrm{b}}$ & 4.88 & 0.91 & 0.69 & $<0.01$ & $<0.01$ & 0.10 & 90.14 & 79.55 & 4.87 \\
\hline $18: 1$ total & $257.45^{\mathrm{c}}$ & $320.29^{\mathrm{ab}}$ & $364.98^{\mathrm{a}}$ & $345.63^{\mathrm{ab}}$ & $334.29^{\mathrm{ab}}$ & $315.40^{\mathrm{ab}}$ & 14.62 & 0.28 & 0.96 & $<0.01$ & 0.06 & 0.23 & 338.63 & 307.38 & 14.00 \\
\hline trans-4 & 0.47 & 0.45 & 0.90 & 0.47 & 3.98 & 0.94 & 1.17 & $<0.01$ & 0.85 & 0.98 & 0.77 & 0.79 & 1.73 & 0.67 & 0.67 \\
\hline trans-5 & 0.63 & 1.41 & 2.38 & 0.82 & 1.13 & 1.99 & 0.59 & 0.62 & 0.94 & 0.63 & 0.15 & 0.06 & 1.55 & 1.23 & 0.33 \\
\hline trans-6/8 & $3.56^{\mathrm{c}}$ & $6.53^{\mathrm{b}}$ & $11.10^{\mathrm{a}}$ & $6.17^{\mathrm{b}}$ & $8.24^{\mathrm{b}}$ & $6.34^{\mathrm{b}}$ & 0.59 & 0.02 & 0.68 & $<0.01$ & 0.82 & $<0.01$ & 7.12 & 6.86 & 0.40 \\
\hline trans-9 & $3.10^{\mathrm{b}}$ & $5.30^{\mathrm{ab}}$ & $7.66^{\mathrm{a}}$ & $5.61^{\mathrm{a}}$ & $7.18^{\mathrm{a}}$ & $7.12^{\mathrm{a}}$ & 0.62 & 0.03 & 0.40 & 0.52 & 0.07 & 0.02 & 6.32 & 5.67 & 0.40 \\
\hline trans-10 & $7.84^{\mathrm{d}}$ & $14.28^{\mathrm{cd}}$ & $24.16^{\mathrm{ab}}$ & $14.53^{\mathrm{cd}}$ & $21.36^{\mathrm{bc}}$ & $29.47^{\mathrm{a}}$ & 2.35 & 0.11 & 0.03 & 0.04 & $<0.01$ & $<0.01$ & 19.04 & 18.17 & 2.24 \\
\hline trans-11 & $16.44^{\mathrm{d}}$ & $23.60^{\mathrm{cd}}$ & $32.52^{\mathrm{bc}}$ & $40.92^{\mathrm{ab}}$ & $54.23^{\mathrm{a}}$ & $54.76^{\mathrm{a}}$ & 4.23 & $<0.01$ & $<0.01$ & $<0.01$ & $<0.01$ & 0.09 & 37.96 & 36.20 & 3.82 \\
\hline trans-12/13 & $4.25^{\mathrm{c}}$ & $7.02^{\mathrm{bc}}$ & $10.85^{\mathrm{abc}}$ & $10.69^{\mathrm{abc}}$ & $12.37^{\mathrm{ab}}$ & $14.81^{\mathrm{a}}$ & 1.80 & 0.14 & 0.12 & 0.11 & 0.10 & 0.95 & 10.99 & 9.02 & 1.02 \\
\hline cis-9 & $197.36^{\mathrm{bc}}$ & $233.57^{\mathrm{a}}$ & $248.23^{\mathrm{a}}$ & $217.04^{\text {ab }}$ & $191.91^{\mathrm{bc}}$ & $166.50^{\mathrm{c}}$ & 9.70 & 0.02 & $<0.01$ & $<0.01$ & $<0.01$ & $<0.01$ & 220.04 & 198.16 & 9.05 \\
\hline cis-11 & $6.23^{\mathrm{ab}}$ & $6.16^{\mathrm{ab}}$ & $6.02^{\mathrm{b}}$ & $8.62^{\mathrm{a}}$ & $6.73^{\mathrm{ab}}$ & $6.81^{\mathrm{ab}}$ & 0.65 & 0.95 & 0.26 & 0.35 & 0.03 & $<0.01$ & 7.32 & 6.21 & 0.47 \\
\hline cis-12 & $3.91^{\mathrm{bc}}$ & $4.42^{\mathrm{bc}}$ & $3.66^{\mathrm{c}}$ & $9.27^{\mathrm{a}}$ & $6.16^{\mathrm{b}}$ & $6.26^{\mathrm{b}}$ & 0.60 & 0.29 & 0.04 & $<0.01$ & $<0.01$ & $<0.01$ & 5.82 & 5.41 & 0.40 \\
\hline cis-13 & $4.36^{\mathrm{c}}$ & $5.23^{\mathrm{bc}}$ & $3.94^{\mathrm{c}}$ & $8.03^{\mathrm{ab}}$ & $8.65^{\mathrm{a}}$ & $8.22^{\mathrm{ab}}$ & 0.81 & $<0.01$ & 0.25 & $<0.01$ & 0.85 & $<0.01$ & 6.41 & 6.40 & 0.69 \\
\hline cis-14+trans-16 & $3.55^{\mathrm{b}}$ & $4.05^{\mathrm{b}}$ & $3.80^{\mathrm{b}}$ & $8.21^{\mathrm{a}}$ & $4.21^{\mathrm{b}}$ & $3.74^{\mathrm{b}}$ & 0.62 & 0.48 & 0.25 & 0.95 & $<0.01$ & $<0.01$ & 4.97 & 4.22 & 0.39 \\
\hline cis-15 & $3.97^{\mathrm{b}}$ & $3.44^{\mathrm{b}}$ & $2.88^{\mathrm{b}}$ & $10.17^{\mathrm{a}}$ & $3.63^{\mathrm{b}}$ & $3.90^{\mathrm{b}}$ & 0.68 & 0.09 & 0.02 & 0.28 & $<0.01$ & $<0.01$ & 5.00 & 4.34 & 0.40 \\
\hline $18: 2$ n- 6 & $26.89^{\mathrm{a}}$ & $24.09^{\text {ab }}$ & $21.83^{\mathrm{b}}$ & $23.44^{\text {ab }}$ & $26.52^{\mathrm{a}}$ & $26.89^{\mathrm{a}}$ & 1.25 & 0.06 & 0.65 & $<0.01$ & 0.05 & 0.25 & 26.25 & 23.41 & 1.21 \\
\hline $18: 3 \mathrm{n}-3$ & $7.23^{\mathrm{a}}$ & $5.69^{\mathrm{b}}$ & $5.14^{\mathrm{bc}}$ & $7.58^{\mathrm{a}}$ & $4.97^{\mathrm{bc}}$ & $4.42^{\mathrm{c}}$ & 0.34 & $<0.01$ & 0.17 & 0.05 & $<0.01$ & $<0.01$ & 6.16 & 5.51 & 0.34 \\
\hline cis-9.trans-11 CLA ${ }^{4}$ & $11.27^{\mathrm{d}}$ & $16.25^{\mathrm{cd}}$ & $19.93^{\mathrm{cd}}$ & $23.98^{\mathrm{bc}}$ & $33.93^{\mathrm{ab}}$ & $35.88^{\mathrm{a}}$ & 2.82 & $<0.01$ & 0.02 & $<0.01$ & $<0.01$ & 0.23 & 24.32 & 22.76 & 2.46 \\
\hline trans-10,cis-12 CLA & $0.52^{\mathrm{b}}$ & $0.61^{\mathrm{ab}}$ & $0.76^{\mathrm{ab}}$ & $0.67^{\mathrm{ab}}$ & $0.77^{\mathrm{a}}$ & $0.80^{\mathrm{a}}$ & 0.06 & 0.12 & 0.26 & 0.63 & 0.11 & 0.26 & 0.73 & 0.65 & 0.03 \\
\hline $20: 0$ & $0.49^{\mathrm{ab}}$ & $0.43^{\mathrm{b}}$ & $0.33^{\mathrm{b}}$ & $0.79^{\mathrm{a}}$ & $0.33^{\mathrm{b}}$ & $0.37^{\mathrm{b}}$ & 0.08 & 0.07 & 0.44 & 0.70 & $<0.01$ & $<0.01$ & 0.50 & 0.41 & 0.05 \\
\hline Unidentified peak & $18.90^{\mathrm{b}}$ & $15.74^{\mathrm{b}}$ & $13.79^{\mathrm{b}}$ & $38.00^{\mathrm{a}}$ & $17.44^{\mathrm{b}}$ & $12.80^{\mathrm{b}}$ & 1.98 & 0.23 & 0.02 & 0.70 & $<0.01$ & $<0.01$ & 19.60 & 19.29 & 1.39 \\
\hline
\end{tabular}

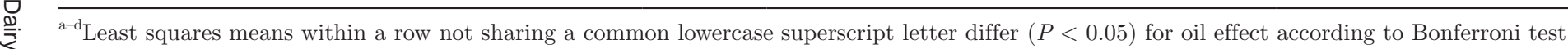

(5) ${ }^{\mathrm{A}, \mathrm{B}}$ Least squares means within a row not sharing a common uppercase superscript letter differ $(P<0.05)$ for Agrado effect.

$\stackrel{\circ}{\frac{\Omega}{\Phi}} \quad{ }^{1} \mathrm{FA}$ yields were calculated based on the estimation that total FA account for $93.3 \%$ of milk total lipids (Glasser et al., 2007).

ঠ $\quad{ }^{2} \mathrm{PO}=$ palm oil; SAF = high-oleic safflower oil; LNSD = linseed oil; CO = corn oil; LSAF = high-linoleic safflower oil.

${ }^{3} 1=$ control vs. oil; $2=$ PO vs. other oils; $3=$ OSAF vs. LSAF; $4=$ LSAF vs. LNSD; $5=$ OSAF vs. LNSD.

$\stackrel{4}{\circ}$ Conjugated linoleic acid. 
Table 5. Fatty acid composition of experimental diets

\begin{tabular}{lrrrrrr}
\hline & \multicolumn{7}{c}{ Treatment $^{1}$} \\
\cline { 2 - 7 } $\begin{array}{l}\text { Fatty acid } \\
\text { (g/kg of DM diet) }\end{array}$ & Control & PO & OSAF & LNSD & CO & LSAF \\
\hline $\mathrm{C}_{12: 0}$ & 1.06 & 1.24 & 1.09 & 1.09 & 1.09 & 1.09 \\
$\mathrm{C}_{14: 0}$ & 0.23 & 1.00 & 0.54 & 0.55 & 0.54 & 0.59 \\
$\mathrm{C}_{16: 0}$ & 4.13 & 22.37 & 6.34 & 6.46 & 9.70 & 7.25 \\
cis-9 $\mathrm{C}_{16: 1}$ & 0.18 & 0.26 & 0.24 & 0.21 & 0.23 & 0.23 \\
$\mathrm{C}_{18: 0}$ & 0.82 & 2.79 & 1.83 & 3.17 & 1.74 & 2.15 \\
$\mathrm{C}_{18: 1}$, total & 3.18 & 23.72 & 42.87 & 14.05 & 16.99 & 10.48 \\
$\mathrm{C}_{18: 2}, \mathrm{n}-6$ & 6.81 & 11.93 & 13.11 & 14.48 & 36.57 & 44.45 \\
$\mathrm{C}_{18: 3}, \mathrm{n}-3$ & 4.02 & 4.27 & 4.38 & 28.90 & 4.65 & 4.08 \\
$\mathrm{C}_{18: 3}, \mathrm{n}-6$ & 0.26 & 0.26 & 0.26 & 0.66 & 0.26 & 0.26 \\
cis-9, trans-11 CLA ${ }^{2}$ & 0.00 & 0.03 & 0.05 & 0.00 & 0.00 & 0.00 \\
trans-10, cis-12 CLA & 0.00 & 0.01 & 0.00 & 0.18 & 0.00 & 0.00 \\
Total & 27.07 & 73.76 & 76.52 & 75.53 & 77.72 & 76.53 \\
\hline${ }^{1}$ PO = palm oil; SAF $=$ high-oleic safflower oil; LNSD $=$ linseed oil; CO = corn oil; LSAF = high-linoleic saf- \\
flower oil.
\end{tabular}

with cows fed oils rich in $\mathrm{C}_{18: 3}$. Our results support their observation by showing that $\mathrm{C}_{18: 2^{2}}$-rich LSAF is more effective in enhancing trans- $11 \mathrm{C}_{18: 1}$ and cis- 9 , trans-11 CLA proportions and yields in milk fat than is $\mathrm{C}_{18: 3^{-}}$ rich LNSD (Tables 4 and 6).

Milk fat yield in response to lipid supplementation is the result of 2 additive phenomena: an initial positive response in milk $\mathrm{C}_{18}$ yield, which decreases with greater amounts of added oil, and a linear decrease in $\mathrm{C}_{<16}$ yield (Glasser et al., 2008). Data from our study showed that feeding $\mathrm{C}_{18: 2}$-rich oils (CO and LSAF) resulted in a more pronounced decrease in $\mathrm{C}_{<16}$ yield than feeding control and PO (Table 4). Feeding $\mathrm{C}_{18: 2^{-}}$ rich LSAF even decreased milk fat yield compared with feeding $\mathrm{C}_{18: 1}$-rich OSAF and $\mathrm{C}_{18: 3}$-rich LNSD. This suggests that supplementing $\mathrm{C}_{18: 2}$-rich oils is a more important cause of MFD than supplementing either $\mathrm{C}_{18: 1^{-}}$or $\mathrm{C}_{18: 3}$-rich oil. Dietary supply of long-chain unsaturated FA has been shown to increase their secretion in milk fat and decrease the de novo synthesis of short- and medium-chain FA in the mammary gland (Grummer, 1991). Our results clearly demonstrated that the increased mammary gland uptake of long-chain FA from unsaturated FA feeding could not fully compensate for the decreased secretion of $\mathrm{C}_{<16} \mathrm{FA}$, which are mostly synthesized de novo. The proportion and yield of total $\mathrm{C}_{18: 1}$ were greater when cows were fed any of the 5 oils compared with the control in our study. The proportion of $\mathrm{C}_{18: 2}$ in total milk $\mathrm{FA}$ was greater in the $\mathrm{CO}$ and LSAF treatments, and the $\mathrm{C}_{18: 3}$ proportion was greater in LNSD, reflecting the dominant FA in these oils.

An increase in milk fat trans- $10 \mathrm{C}_{18: 1}$ has been consistently observed when cows are fed diets causing MFD (Shingfield and Griinari, 2007). Postruminal infusion of $42.6 \mathrm{~g} / \mathrm{d}$ trans $-10 \mathrm{C}_{18: 1}$ did not reduce milk fat synthesis (Lock et al., 2007). However, a recent abomasal infusion study showed that infusing a mixture of $\mathrm{C}_{18: 1}$ fatty acid methyl esters supplying $92.1 \mathrm{~g} / \mathrm{d}$ trans-10 $\mathrm{C}_{18: 1}$ reduced milk fat secretion (Shingfield et al., 2009). These data suggest that trans-10 $\mathrm{C}_{18: 1}$ is potentially antilipogenic and may contribute to the diet-induced MFD, considering the relative abundance of trans-10 $\mathrm{C}_{18: 1}$ in the treatment (Shingfield et al., 2009). Previous literature confirmed that the proportions of trans-10 $\mathrm{C}_{18: 1}$ and trans10, cis-12 CLA in total milk FA are negatively correlated to milk fat concentration in cows fed high-concentrate diets with or without unsaturated oils (Bauman and Griinari, 2003). In our study, feeding $\mathrm{C}_{18: 2}$-rich $\mathrm{CO}$ and LSAF, which significantly decreased milk fat concentration and yield, increased milk trans-10, cis-12 CLA proportion and resulted in 3.5- and 5.8-fold increases in milk trans-10 $\mathrm{C}_{18: 1}$ proportion, respectively, compared with control (Table 6). Feeding CO and LSAF also significantly increased milk trans-10, cis-12 CLA yield compared with control $(P<0.05$; Table 4). Studies have clearly established that trans-10,cis-12 CLA is a potent inhibitor of milk fat synthesis in the dairy cow (Baumgard et al., 2001, 2002; Peterson et al., 2002). Furthermore, a diminishing effect on milk fat yield is observed, with increasing abomasal infusion rates of trans-10,cis-12 CLA (Baumgard et al., 2001). However, previous work also showed discrepancies between trans10,cis-12 CLA and milk fat yield (Loor et al., 2005a) or even no correlation between milk trans-10, cis-12 CLA and milk fat concentration (Bradford and Allen, 2004; Loor et al., 2005b). Moreover, for studies with a similar degree of MFD, trans-10,cis-12 CLA as a proportion of milk FA is normally greater when trans-10, cis-12 CLA is infused postruminally compared with studies with diet-induced MFD (Bell et al., 2006). This suggests that other milk fat synthesis inhibitors in addition to trans-10, cis-12 CLA exert antilipogenic effects and are 
Table 6. Effect of vegetable oil and Agrado Plus (Novus International, St. Charles, MO) supplementation on milk fatty acid (FA) composition

\begin{tabular}{|c|c|c|c|c|c|c|c|c|c|c|c|c|c|c|c|}
\hline \multirow{2}{*}{$\begin{array}{l}\text { FA }(g / 100 \mathrm{~g} \\
\text { of FA) }\end{array}$} & \multicolumn{6}{|c|}{ Oil treatment ${ }^{1}$} & \multirow[b]{2}{*}{ SEM } & \multicolumn{5}{|c|}{ Contrast,${ }^{2} P$-value } & \multicolumn{2}{|c|}{ Agrado treatment } & \multirow[b]{2}{*}{ SEM } \\
\hline & Control & $\mathrm{PO}$ & OSAF & LNSD & $\mathrm{CO}$ & LSAF & & 1 & 2 & 3 & 4 & 5 & - & + & \\
\hline $4: 0$ & 4.01 & 3.84 & 3.59 & 3.78 & 3.50 & 3.39 & 0.24 & 0.27 & 0.49 & 0.45 & 0.13 & 0.44 & 3.85 & 3.52 & 0.23 \\
\hline 6:0 & $2.35^{\mathrm{a}}$ & $1.83^{\mathrm{b}}$ & $1.63^{\mathrm{b}}$ & $1.64^{\mathrm{b}}$ & $1.48^{\mathrm{b}}$ & $1.53^{\mathrm{b}}$ & 0.11 & $<0.01$ & 0.71 & 0.40 & 0.36 & 0.94 & 1.78 & 1.71 & 0.11 \\
\hline $8: 0$ & $1.30^{\mathrm{a}}$ & $0.83^{\mathrm{b}}$ & $0.78^{\mathrm{b}}$ & $0.78^{\mathrm{b}}$ & $0.69^{\mathrm{b}}$ & $0.67^{\mathrm{b}}$ & 0.05 & $<0.01$ & 0.24 & 0.04 & 0.06 & 0.89 & 0.87 & 0.82 & 0.05 \\
\hline 10:0 & $2.74^{\mathrm{a}}$ & $1.57^{\mathrm{b}}$ & $1.50^{\mathrm{b}}$ & $1.49^{\mathrm{b}}$ & $1.35^{\mathrm{b}}$ & $1.34^{\mathrm{b}}$ & 0.10 & $<0.01$ & 0.05 & 0.21 & 0.22 & 0.98 & 1.71 & 1.62 & 0.08 \\
\hline 12:0 & $3.43^{\mathrm{a}}$ & $1.97^{\mathrm{b}}$ & $2.00^{\mathrm{b}}$ & $1.94^{\mathrm{b}}$ & $1.80^{\mathrm{b}}$ & $1.84^{\mathrm{b}}$ & 0.11 & $<0.01$ & $<0.01$ & 0.25 & 0.48 & 0.66 & 2.19 & 2.14 & 0.08 \\
\hline 14:0 & $10.77^{\mathrm{a}}$ & $7.64^{\mathrm{b}}$ & $8.09^{\mathrm{b}}$ & $7.75^{\mathrm{b}}$ & $7.29^{\mathrm{b}}$ & $7.57^{\mathrm{b}}$ & 0.25 & $<0.01$ & $<0.01$ & 0.13 & 0.59 & 0.32 & 8.20 & 8.17 & 0.16 \\
\hline $14: 1$ & $1.16^{\mathrm{a}}$ & $0.88^{\mathrm{b}}$ & $1.05^{\mathrm{ab}}$ & $0.91^{\mathrm{b}}$ & $0.86^{\mathrm{b}}$ & $0.95^{\mathrm{ab}}$ & 0.07 & 0.03 & 0.03 & 0.18 & 0.67 & 0.08 & 1.01 & 0.92 & 0.06 \\
\hline 15:0 & $1.06^{\mathrm{a}}$ & $0.73^{\mathrm{b}}$ & $0.80^{\mathrm{b}}$ & $0.77^{\mathrm{b}}$ & $0.74^{\mathrm{b}}$ & $0.77^{\mathrm{b}}$ & 0.02 & $<0.01$ & $<0.01$ & 0.29 & 0.99 & 0.28 & 0.81 & 0.81 & 0.02 \\
\hline$<16: 0$ & $28.16^{\mathrm{a}}$ & $20.21^{\mathrm{b}}$ & $20.33^{\mathrm{b}}$ & $19.97^{\mathrm{b}}$ & $18.54^{\mathrm{b}}$ & $18.86^{\mathrm{b}}$ & 0.80 & $<0.01$ & 0.05 & 0.14 & 0.26 & 0.72 & 21.39 & 20.63 & 0.63 \\
\hline $16: 0$ & $27.53^{\mathrm{b}}$ & $30.99^{\mathrm{a}}$ & $21.46^{\mathrm{c}}$ & $19.82^{\mathrm{c}}$ & $21.68^{\mathrm{c}}$ & $21.32^{\mathrm{c}}$ & 0.80 & $<0.01$ & $<0.01$ & 0.90 & 0.16 & 0.13 & 23.96 & 23.64 & 0.52 \\
\hline $16: 1$ cis -9 & $2.03^{\mathrm{b}}$ & $2.64^{\mathrm{a}}$ & $1.97^{\mathrm{b}}$ & $1.74^{\mathrm{b}}$ & $1.92^{\mathrm{b}}$ & $1.96^{\mathrm{b}}$ & 0.12 & 0.14 & $<0.01$ & 0.94 & 0.09 & 0.08 & 2.13 & 1.96 & 0.11 \\
\hline $17: 0$ & $0.38^{\mathrm{a}}$ & $0.27^{\mathrm{b}}$ & $0.30^{\mathrm{b}}$ & $0.30^{\mathrm{b}}$ & $0.29^{\mathrm{b}}$ & $0.31^{\mathrm{b}}$ & 0.01 & 0.07 & $<0.01$ & 0.73 & 0.64 & 0.90 & 0.31 & 0.31 & 0.01 \\
\hline 18:0 & $7.79^{\mathrm{b}}$ & $7.49^{\mathrm{b}}$ & $10.39^{\mathrm{a}}$ & $9.63^{\mathrm{a}}$ & $9.44^{\mathrm{a}}$ & $9.48^{\mathrm{a}}$ & 0.31 & 0.10 & $<0.01$ & 0.02 & 0.68 & 0.05 & 9.05 & 9.02 & 0.27 \\
\hline $18: 1$ total & $25.15^{\mathrm{c}}$ & $29.34^{\mathrm{b}}$ & $39.49^{\mathrm{a}}$ & $38.11^{\mathrm{a}}$ & $37.56^{\mathrm{a}}$ & $40.40^{\mathrm{a}}$ & 1.02 & $<0.01$ & $<0.01$ & 0.47 & 0.06 & 0.26 & 34.53 & 35.49 & 0.88 \\
\hline trans-4 & 0.04 & 0.04 & 0.09 & 0.05 & 0.37 & 0.11 & 0.10 & $<0.01$ & 0.75 & 0.90 & 0.66 & 0.75 & 0.16 & 0.08 & 0.06 \\
\hline trans-5 & 0.06 & 0.15 & 0.24 & 0.10 & 0.12 & 0.28 & 0.07 & 0.57 & 0.77 & 0.67 & 0.06 & 0.15 & 0.18 & 0.14 & 0.04 \\
\hline trans- $6 / 8$ & $0.35^{\mathrm{d}}$ & $0.60^{\mathrm{cd}}$ & $1.21^{\mathrm{a}}$ & $0.70^{\mathrm{bc}}$ & $0.97^{\mathrm{ab}}$ & $0.86^{\mathrm{bc}}$ & 0.08 & $<0.01$ & 0.02 & $<0.01$ & 0.09 & $<0.01$ & 0.74 & 0.82 & 0.06 \\
\hline trans-9 & $0.31^{\mathrm{d}}$ & $0.48^{\mathrm{cd}}$ & $0.83^{\mathrm{ab}}$ & $0.63^{\mathrm{bc}}$ & $0.81^{\mathrm{ab}}$ & $0.92^{\mathrm{a}}$ & 0.06 & 0.01 & $<0.01$ & 0.33 & $<0.01$ & 0.02 & 0.66 & 0.67 & 0.04 \\
\hline trans-10 & $0.77^{\mathrm{c}}$ & $1.35^{\mathrm{c}}$ & $2.71^{\mathrm{b}}$ & $1.71^{\mathrm{bc}}$ & $2.69^{\mathrm{b}}$ & $4.49^{\mathrm{a}}$ & 0.38 & 0.13 & $<0.01$ & $<0.01$ & $<0.01$ & 0.02 & 2.18 & 2.39 & 0.37 \\
\hline trans-11 & $1.61^{\mathrm{c}}$ & $2.21^{\mathrm{c}}$ & $3.54^{\mathrm{b}}$ & $4.53^{\mathrm{b}}$ & $5.87^{\mathrm{a}}$ & $6.41^{\mathrm{a}}$ & 0.33 & $<0.01$ & $<0.01$ & $<0.01$ & $<0.01$ & 0.02 & 3.88 & 4.18 & 0.25 \\
\hline trans-12/13 & $0.42^{\mathrm{c}}$ & $0.65^{\mathrm{bc}}$ & $1.16^{\mathrm{ab}}$ & $1.14^{\mathrm{abc}}$ & $1.31^{\mathrm{ab}}$ & $1.74^{\mathrm{a}}$ & 0.18 & 0.13 & 0.02 & 0.02 & 0.02 & 0.93 & 1.10 & 1.04 & 0.10 \\
\hline cis-9 & $19.24^{\mathrm{c}}$ & $21.31^{\mathrm{c}}$ & $26.76^{\mathrm{a}}$ & $23.86^{\mathrm{b}}$ & $21.68^{\mathrm{bc}}$ & $21.30^{\mathrm{c}}$ & 0.71 & 0.20 & 0.03 & $<0.01$ & $<0.01$ & $<0.01$ & 22.13 & 22.59 & 0.63 \\
\hline cis-11 & $0.60^{\mathrm{c}}$ & $0.56^{\mathrm{c}}$ & $0.65^{\mathrm{bc}}$ & $0.93^{\mathrm{a}}$ & $0.73^{\mathrm{abc}}$ & $0.84^{\mathrm{ab}}$ & 0.06 & 0.89 & $<0.01$ & 0.01 & 0.25 & $<0.01$ & 0.74 & 0.70 & 0.04 \\
\hline cis-12 & $0.39^{\mathrm{c}}$ & $0.40^{\mathrm{c}}$ & $0.40^{\mathrm{c}}$ & $1.01^{\mathrm{a}}$ & $0.67^{\mathrm{b}}$ & $0.78^{\mathrm{b}}$ & 0.05 & 0.19 & $<0.01$ & $<0.01$ & $<0.01$ & $<0.01$ & 0.60 & 0.62 & 0.03 \\
\hline cis-13 & $0.44^{\mathrm{b}}$ & $0.50^{\mathrm{b}}$ & $0.44^{\mathrm{b}}$ & $0.89^{\mathrm{a}}$ & $0.96^{\mathrm{a}}$ & $1.08^{\mathrm{a}}$ & 0.08 & $<0.01$ & 0.02 & $<0.01$ & 0.08 & $<0.01$ & 0.68 & 0.76 & 0.05 \\
\hline cis-14+trans-16 & $0.35^{\mathrm{b}}$ & $0.37^{\mathrm{b}}$ & $0.42^{\mathrm{b}}$ & $0.89^{\mathrm{a}}$ & $0.46^{\mathrm{b}}$ & $0.49^{\mathrm{b}}$ & 0.06 & 0.47 & 0.01 & 0.35 & $<0.01$ & $<0.01$ & 0.51 & 0.48 & 0.03 \\
\hline cis-15 & $0.41^{\mathrm{b}}$ & $0.34^{\mathrm{b}}$ & $0.32^{\mathrm{b}}$ & $1.11^{\mathrm{a}}$ & $0.41^{\mathrm{b}}$ & $0.53^{\mathrm{b}}$ & 0.07 & 0.10 & $<0.01$ & 0.04 & $<0.01$ & $<0.01$ & 0.53 & 0.51 & 0.04 \\
\hline $18: 2 \mathrm{n}-6$ & $2.62^{\mathrm{b}}$ & $2.22^{\mathrm{c}}$ & $2.36^{\mathrm{bc}}$ & $2.57^{\mathrm{bc}}$ & $2.99^{\mathrm{a}}$ & $3.34^{\mathrm{a}}$ & 0.09 & $<0.01$ & $<0.01$ & $<0.01$ & $<0.01$ & 0.08 & 2.66 & 2.70 & 0.07 \\
\hline $18: 3$ n-3 & $0.72^{\mathrm{b}}$ & $0.53^{\mathrm{c}}$ & $0.56^{\mathrm{c}}$ & $0.82^{\mathrm{a}}$ & $0.55^{\mathrm{c}}$ & $0.56^{\mathrm{c}}$ & 0.02 & $<0.01$ & $<0.01$ & 0.76 & $<0.01$ & $<0.01$ & 0.62 & 0.63 & 0.02 \\
\hline cis-9,trans-11 CLA ${ }^{3}$ & $1.10^{\mathrm{d}}$ & $1.51^{\mathrm{cd}}$ & $2.16^{\mathrm{bc}}$ & $2.67^{\mathrm{b}}$ & $3.68^{\mathrm{a}}$ & $4.09^{\mathrm{a}}$ & 0.22 & $<0.01$ & $<0.01$ & $<0.01$ & $<0.01$ & 0.08 & 2.47 & 2.60 & 0.17 \\
\hline trans-10, cis-12 CLA & $0.05^{\mathrm{c}}$ & $0.06^{\mathrm{bc}}$ & $0.09^{\mathrm{ab}}$ & $0.08^{\mathrm{bc}}$ & $0.09^{\mathrm{ab}}$ & $0.12^{\mathrm{a}}$ & 0.009 & 0.15 & 0.02 & $<0.01$ & $<0.01$ & 0.37 & 0.08 & 0.08 & 0.006 \\
\hline 20:0 & $0.05^{\mathrm{ab}}$ & $0.04^{\mathrm{b}}$ & $0.03^{\mathrm{b}}$ & $0.08^{\mathrm{a}}$ & $0.04^{\mathrm{b}}$ & $0.05^{\mathrm{ab}}$ & 0.009 & 0.09 & 0.12 & 0.22 & $<0.01$ & $<0.01$ & 0.05 & 0.04 & 0.006 \\
\hline Unidentified peak & $1.88^{\mathrm{b}}$ & $1.51^{\mathrm{b}}$ & $1.49^{\mathrm{b}}$ & $4.09^{\mathrm{a}}$ & $1.94^{\mathrm{b}}$ & $1.71^{\mathrm{b}}$ & 0.18 & 0.31 & $<0.01$ & 0.38 & $<0.01$ & $<0.01$ & 1.99 & 2.22 & 0.10 \\
\hline
\end{tabular}

( ${ }^{\mathrm{a}-\mathrm{d}}$ Least squares means within a row not sharing a common lowercase superscript letter differ $(P<0.05)$ for oil effect according to Bonferroni test.

$\stackrel{\frac{\Omega}{\Phi}}{\stackrel{1}{D}} \quad{ }^{1} \mathrm{PO}=$ palm oil; $\mathrm{SAF}=$ high-oleic safflower oil; LNSD = linseed oil; $\mathrm{CO}=$ corn oil; LSAF $=$ high-linoleic safflower oil

శ్రి ${ }^{2} 1=$ control vs. oil; $2=$ PO vs. other oils; $3=$ OSAF vs. LSAF; $4=$ LSAF vs. LNSD; $5=$ OSAF vs. LNSD

$\lesssim \quad{ }^{3}$ Conjugated linoleic acid. 
involved in diet-induced MFD (Bauman and Griinari, 2003; Peterson et al., 2003; Loor et al., 2005b).

As we expected, milk $\mathrm{C}_{18: 3}$ yield was significantly greater when feeding LNSD compared with feeding other oils, presumably because linseed oil is rich in $\mathrm{C}_{18: 3}$ (Table 4). Feeding PO, OSAF, CO, and LSAF dramatically inhibited milk $\mathrm{C}_{18: 3}$ secretion compared with control, despite a similar dietary supply of $\mathrm{C}_{18: 3}$ among these 5 treatments.

Milk FA yields were not affected by Agrado Plus feeding in this trial. This is in accordance with results from a previous study in which insignificant milk FA yield differences were observed between treatments when Agrado Plus was fed (Vazquez-Anon et al., 2008). We found no significant Agrado Plus by oil interaction for any of the FA analyzed. In both studies, Agrado Plus supplementation did not inhibit the secretion of FA associated with MFD such as trans-10 $\mathrm{C}_{18: 1}$ or trans10, cis-12 CLA.

\section{CONCLUSIONS}

A negative effect on milk fat yield and concentration is associated primarily with unprotected oils rich in $\mathrm{C}_{18: 2}$. It is not clear from this study whether $\mathrm{C}_{18: 1}$ and $\mathrm{C}_{18: 3}$ had negative effects on milk fat yield or if the MFD with high-oleic safflower oil and linseed oil were due to the $\mathrm{C}_{18: 2}$ content; however, if these $\mathrm{FA}$ depressed milk fat yield they appeared to be equal in potency to each other and less potent than linoleic acid. Although palm oil contained $\mathrm{C}_{18: 2}$ and showed decreased yield of milk $\mathrm{C}_{<16}$, the increased $\mathrm{C}_{16: 0}$ yield more than offset this decrease so that milk fat yield was at least equal to that on control. We observed no main effect of Agrado feeding nor any Agrado by oil interaction effect for any milk production or fatty acid parameter.

\section{ACKNOWLEDGMENTS}

The authors thank Jerry Guenther and his staff at UW-Madison Dairy Cattle Center for animal care, feeding, and sample collection; UW-Madison Dairy Cattle Nutrition Laboratory manager Sandy Bertics for assisting with trial management and laboratory milk fatty acids GC analyses; Peter Crump of UW-Madison CALS for assisting with statistical analyses; Mercedes Vazquez-Anon and Gavin Bowman of Novus International Inc. (St. Charles, MO) for technical support; Novus International Inc. for financial supporting and for donating the Agrado Plus supplement; and Hangshu Xin of China Agricultural University for sample collection and analyses.

\section{REFERENCES}

Abdelqader, M. M., A. R. Hippen, K. F. Kalscheur, D. J. Schingoethe, and A. D. Garcia. 2009. Isolipidic additions of fat from corn germ, corn distillers grains, or corn oil in dairy cow diets. J. Dairy Sci. 92:5523-5533.

AlZahal, O., N. E. Odongo, T. Mutsvangwa, M. M. Or-Rashid, T. F. Duffield, R. Bagg, P. Dick, G. Vessie, and B. W. McBride. 2008. Effects of monensin and dietary soybean oil on milk fat percentage and milk fatty acid profile in lactating dairy cows. J. Dairy Sci. 91:1166-1174

Andrews, J., M. Vazquez-Anon, and G. Bowman. 2006. Fat stability and preservation of fatty acids with Agrado antioxidant in feed ingredients used in ruminant rations. J. Dairy Sci. 89(Suppl. 1):60. (Abstr.)

AOAC. 1997. Official Methods of Analysis. 16th ed. AOAC Intl., Gaithersburg, MD.

Banks, W., J. L. Clapperton, M. E. Ferrie, and A. G. Wilson. 1976. Effects of feeding fat to dairy cows receiving a fat-deficient basal diet. I. Milk yield and composition. J. Dairy Res. 43:213-218.

Bauman, D. E., and J. M. Griinari. 2001. Regulation and nutritional manipulation of milk fat: Low-fat milk syndrome. Livest. Prod. Sci. 70:15-29.

Bauman, D. E., and J. M. Griinari. 2003. Nutritional regulation of milk fat synthesis. Annu. Rev. Nutr. 23:203-227.

Baumgard, L. H., E. Matitashvili, B. A. Corl, D. A. Dwyer, and D. E. Bauman. 2002. Trans-10, cis-12 conjugated linoleic acid decreases lipogenic rates and expression of genes involved in milk lipid synthesis in dairy cows. J. Dairy Sci. 85:2155-2163.

Baumgard, L. H., J. K. Sangster, and D. E. Bauman. 2001. Milk fat synthesis in dairy cows is progressively reduced by increasing supplemental amounts of trans-10, cis-12 conjugated linoleic acid (CLA). J. Nutr. 131:1764-1769.

Bell, J. A., J. M. Griinari, and J. J. Kennelly. 2006. Effect of safflower oil, flaxseed oil, monensin, and vitamin $\mathrm{E}$ on concentration of conjugated linoleic acid in bovine milk fat. J. Dairy Sci. $89: 733-748$.

Bradford, B. J., and M. S. Allen. 2004. Milk fat responses to a change in diet fermentability vary by production level in dairy cattle. J. Dairy Sci. 87:3800-3807.

Brzezinska-Slebodzinska, E., J. K. Miller, J. D. Quigley III, J. R. Moore, and F. C. Madsen. 1994. Antioxidant status of dairy cows supplemented prepartum with vitamin E and selenium. J. Dairy Sci. 77:3087-3095.

Bu, D. P., J. Q. Wang, T. R. Dhiman, and S. J. Liu. 2007. Effectiveness of oils rich in linoleic and linolenic acids to enhance conjugated linoleic acid in milk from dairy cows. J. Dairy Sci. 90:998-1007.

Chilliard, Y. 1993. Dietary fat and adipose tissue metabolism in ruminants, pigs, and rodents: A review. J. Dairy Sci. 76:3897-3931.

Chilliard, Y., C. Martin, J. Rouel, and M. Doreau. 2009. Milk fatty acids in dairy cows fed whole crude linseed, extruded linseed, or linseed oil, and their relationship with methane output. J. Dairy Sci. 92:5199-5211.

Chouinard, P. Y., L. Corneau, D. M. Barbano, L. E. Metzger, and D. E. Bauman. 1999. Conjugated linoleic acids alter milk fatty acid composition and inhibit milk fat secretion in dairy cows. J. Nutr. 129:1579-1584.

Chouinard, P. Y., L. Corneau, D. E. Bauman, W. R. Butler, Y Chilliard, and J. K. Drackley. 1998. Conjugated linoleic acid content of milk from cows fed different sources of dietary fat. J. Dairy Sci. 81(Suppl. 1):233. (Abstr.)

Corl, B. A., L. H. Baumgard, D. A. Dwyer, J. M. Griinari, B. S. Phillips, and D. E. Bauman. 2001. The role of $\Delta$ 9-desaturase in the production of cis-9, trans-11 CLA. J. Nutr. Biochem. 12:622630.

Davis, C. L., and R. E. Brown. 1970. Low-fat milk syndrome. Pages 545-565 in Physiology of Digestion and Metabolism in the Ruminant. A. T. Phillipson, ed. Oriel Press, Newcastle upon Tyne, UK. 
DePeters, E. J., and J. P. Cant. 1992. Nutritional factors influencing the nitrogen composition of bovine milk: A review. J. Dairy Sci. 75:2043-2070.

DePeters, E. J., J. B. German, S. J. Taylor, S. T. Essex, and H. PerezMonti. 2001. Fatty acid and triglyceride composition of milk fat from lactating Holstein cows in response to supplemental canola oil. J. Dairy Sci. 84:929-936.

Dhiman, T. R., L. D. Satter, M. W. Pariza, M. P. Galli, K. Albright, and M. X. Tolosa. 2000. Conjugated linoleic acid (CLA) content of milk from cows offered diets rich in linoleic and linolenic acid. J. Dairy Sci. 83:1016-1027.

Enjalbert, F., M. C. Nicot, C. Bayourthe, and R. Moncoulon. 2000. Effects of duodenal infusions of palmitic, stearic, or oleic acids on milk composition and physical properties of butter. J. Dairy Sci. 83:1428-1433.

Glasser, F., M. Doreau, A. Ferlay, and Y. Chilliard. 2007. Technical note: Estimation of milk fatty acid yield from milk fat data. J. Dairy Sci. 90:2302-2304.

Glasser, F., A. Ferlay, and Y. Chilliard. 2008. Oilseed lipid supplements and fatty acid composition of cow milk: A meta-analysis. J. Dairy Sci. 91:4687-4703.

Goering, H. K., and P. J. Van Soest. 1970. Forage Fiber Analysis (Apparatus, reagents, procedures, and some applications). Modified per D. R. Mertens. Handbook Number 379. USDA Agricultural Research Service, Washington, DC.

Griinari, J. M., and D. E. Bauman. 1999. Biosynthesis of conjugated linoleic acid and its incorporation into meat and milk in ruminants. Pages 180-200 in Advances in Conjugated Linoleic Acid Research. Vol. 1. M. P. Yurawecz, M. M. Mossoba, J. K. G. Kramer, M. W. Pariza, and G. Nelson, ed. AOCS Press, Champaign, IL.

Grummer, R. R. 1991. Effect of feed on the composition of milk fat. J. Dairy Sci. 74:3244-3257.

Huang, Y., J. P. Schoonmaker, B. J. Bradford, and D. C. Beitz. 2008. Response of milk fatty acid composition to dietary supplementation of soy oil, conjugated linoleic acid, or both. J. Dairy Sci. 91:260-270.

Jenkins, T. C. 1998. Fatty acid composition of milk from Holstein cows fed oleamide or canola oil. J. Dairy Sci. 81:794-800.

Jenkins, T. C., and M. A. McGuire. 2006. Major advances in nutrition: Impact on milk composition. J. Dairy Sci. 89:1302-1310.

Kelly, M. L., J. R. Berry, D. A. Dwyer, J. M. Griinari, P. Y. Chouinard, M. E. Van Amburgh, and D. E. Bauman. 1998. Dietary fatty acid sources affect conjugated linoleic acid concentrations in milk from lactating dairy cows. J. Nutr. 128:881-885.

Bach Knudsen, K. E. 1997. Carbohydrate and lignin contents of plant materials used in animal feeding. Anim. Feed Sci. Technol. 67:319-338.

Leonardi, C., S. Bertics, and L. E. Armentano. 2005. Effect of increasing oil from distillers grains or corn oil on lactation performance. J. Dairy Sci. 88:2820-2827.

Lock, A. L., and P. C. Garnsworthy. 2002. Independent effects of dietary linoleic and linolenic fatty acids on the conjugated linoleic acid content of cows' milk. Anim. Sci. 74:163-176.

Lock, A. L., C. Tyburczy, D. A. Dwyer, K. J. Harvatine, F. Destaillats, Z. Mouloungui, L. Candy, and D. E. Bauman. 2007. Trans-10 octadecenoic acid does not reduce milk fat synthesis in dairy cows. J. Nutr. 137:71-76.

Loor, J. J., A. Ferlay, A. Ollier, M. Doreau, and Y. Chilliard. 2005a. Relationship among trans and conjugated fatty acids and bovine milk fat yield due to dietary concentrate and linseed oil. J. Dairy Sci. 88:726-740

Loor, J. J., A. Ferlay, A. Ollier, K. Ueda, M. Doreau, and Y. Chilliard. 2005b. High-concentrate diets and polyunsaturated oils alter trans and conjugated isomers in bovine rumen, blood, and milk. J. Dairy Sci. 88:3986-3999.

McGuire, M. A., and M. K. McGuire. 2000. Conjugated linoleic acid (CLA): A ruminant fatty acid with beneficial effects on human health. J. Anim Sci. 77(E-Suppl.):1-8.

Nobles, R. C., W. Steele, and J. H. Moore. 1969. The effects of dietary palmitic and stearic acids on milk fat composition in the cow. J. Dairy Res. 36:375-381.

NRC. 2001. Nutrient Requirements of Dairy Cattle. 7th rev. ed. Natl. Acad. Sci., Washington, DC.

Pantoja, J., J. L. Firkins, M. L. Eastridge, and B. L. Hull. 1994. Effects of fat saturation and source of fiber on site of nutrient digestion and milk production by lactating dairy cows. J. Dairy Sci. 77:2341-2356

Perfield, J. W. II, A. L. Lock, J. M. Griinari, A. Sæbø, P. Delmonte, D. A. Dwyer, and D. E. Bauman. 2007. Trans-9, cis-11 conjugated linoleic acid reduces milk fat synthesis in lactating dairy cows. J. Dairy Sci. 90:2211-2218.

Peterson, D. G., L. H. Baumgard, and D. E. Bauman. 2002. Short communication: Milk fat response to low doses of trans-10, cis-12 conjugated linoleic acid (CLA). J. Dairy Sci. 85:1764-1766.

Peterson, D. G., E. A. Matitashvili, and D. E. Bauman. 2003. Diet-induced milk fat depression in dairy cows results in increased trans-10, cis-12 CLA in milk fat and coordinate suppression of mRNA abundance for mammary enzymes involved in milk fat synthesis. J. Nutr. 133:3098-3102.

Sæbø, A., P. Sæbø, J. M. Griinari, and K. J. Shingfield. 2005. Effect of abomasal infusion of geometric isomers of 10,12 conjugated linoleic acid on milk fat synthesis in dairy cows. Lipids 40:823-832.

Shingfield, K. J., and J. M. Griinari. 2007. Role of biohydrogenation intermediates in milk fat depression. Eur. J. Lipid Sci. Technol. 109:799-816.

Shingfield, K. J., A. Sæbø, P.-C. Sæbø, V. Toivonen, and J. M. Griinari. 2009. Effect of abomasal infusions of a mixture of octadecenoic acids on milk fat synthesis in lactating cows. J. Dairy Sci. 92:4317-4329.

Sies, H. 1985. Oxidative Stress. Academic Press, New York, NY.

Steele, W., and J. H. Moore. 1968. The effects of a series of saturated fatty acids in the diet on milk-fat secretion in the cow. J. Dairy Res. 35:361-369.

Sukhija, P. S., and D. L. Palmquist. 1988. Rapid method for determination of total fatty acid content and composition in feedstuffs and feces. J. Agric. Food Chem. 36:1202-1206.

Understander, D., D. R. Mertens, and N. Thiex. 1993. Forage Analysis Procedures. Natl. Forage Testing Assoc., Omaha, NE.

Van Soest, P. J., J. B. Robertson, and B. A. Lewis. 1991. Methods for dietary fiber, neutral detergent fiber, and nonstarch polysaccharides in relation to animal nutrition. J. Dairy Sci. 74:3583-3597.

Vázquez-Añón, M., and T. Jenkins. 2007. Effects of feeding oxidized fat with or without dietary antioxidants on nutrient digestibility, microbial nitrogen, and fatty acid metabolism. J. Dairy Sci. 90:4361-4367.

Vázquez-Añón, M., J. Nocek, G. Bowman, T. Hampton, C. Atwell, P. Vazquez, and T. Jenkins. 2008. Effects of feeding a dietary antioxidant in diets with oxidized fat on lactation performance and antioxidant status of the cow. J. Dairy Sci. 91:3165-3172.

Wu, Z., and J. T. Huber. 1994. Relationship between dietary fat supplementation and milk protein concentration in lactating cows: A review. Livest. Prod. Sci. 39:141-155.

Zheng, H. C., J. X. Liu, J. H. Yao, Q. Yuan, H. W. Ye, J. A. Ye, and Y. M. Wu. 2005. Effects of dietary sources of vegetable oils on performance of high-yielding lactating cows and conjugated linoleic acids in milk. J. Dairy Sci. 88:2037-2042. 